\title{
Extravagant Life Style Assessment Scale (ELAS): Development and Validation
}

\author{
Fred Femi Akinfala ${ }^{1}$, Gabriel Aunde Akinbode ${ }^{1} \&$ Folusho Ayodeji $^{1}$ \\ ${ }^{1}$ Department of Psychology, University of Lagos, Nigeria \\ Correspondence: Fred Femi Akinfala, Department of Psychology, University of Lagos, Nigeria. E-mail: \\ fakinfala@unilag.edu.ng
}

Received: May 22, 2014

Accepted: August 11, 2014

Online Published: August 22, 2014

doi:10.5539/ijbm.v9n9p213

URL: http://dx.doi.org/10.5539/ijbm.v9n9p213

\begin{abstract}
A major policy defect in the much Orchestrated phenomenon of corruption in Nigeria, by both governments and the mass media, is the dearth of objective psychological tools for measuring and predicting corrupt behaviour and other forms of psychological malaise. The development and validation of Extravagant Life-style Assessment Scale (ELAS) is one the bold attempt at remediating an aspect of the policy defect in view of the fact that extravagant life style has implication for the manifestation of corrupt and fraudulent behaviour. Using literature review, interviews and focused group discussions, 79 items were generated. Through the processes of panel of expert selection, face validity check and statistical analysis, the 79 items were reduced to 34 . The scale was administered to 600 participants $(\mathrm{M}=378, \mathrm{~F}=222)$ comprising banker's convicted and nonconvicted for fraud, and nonconvicted nonbankers. The normative scores obtained were: convicted bankers $=46.55$, nonconvicted bankers $=33.31$ and nonbankers $=39.79$ comparing the scores of the groups with ANOVA, the result showed that ELAS significantly differentiated the three groups, $\mathrm{F}(2,597)=26.94, \mathrm{P}<.01$, with the convicted bankers having the highest mean score in extravagant life-style. The reliability coefficients obtained were; cronbach alpha internal consistency $=.90$, split-half $=.77$ and odd-even $=.81$. Divergent validity coefficients of .32 and .18 were obtained by correlating ELAS with the Psychoticism sub-scale of EPQ (Adult) and the Psychopathic Deviate Scale respectively. Factor analysing ELAS with principal component and varimax rotation was computed in order to establish its factorial validity. Eight factors with eigenvalues above 1 were extracted. The factors, which account for $60.2 \%$ of the total variance includes the need for: investment, gambling, good life, religiosity, social activities, family and spiritualism. The predictive value of the scale in preventing corrupt and fraudulent behaviours was emphasized.
\end{abstract}

Keywords: extravagant life-style, fraudulent behaviours, corrupt tendencies, get-rich-quick syndrome

\section{Introduction}

Today, to say that corruption and fraudulent behaviour is fast becoming officially acceptable normative behaviour among Nigerians is more or less an understatement. Studies have revealed that anecdotal and documented evidence indicates that corruption is a serious problem in Nigeria (Omoluabi, 1995; Amadi, 2004; Akinfala, 2005; Ajibola, 2007; Abimbola 2007; Hamilton \& Gabriel, 2012; Bamidele, Joseph \& Oresajo, 2013). Precisely, the 1990's to date are a time of unprecedented public debate on the political, legislative, and psychotherapeutic issues of corrupt orientation and blatant extravagant lifestyle of some privileged Nigerian public and private office holders. In a country where many hardworking senior civil servants and even people in the private sector can barely make ends meet, certain individuals due to auspicious public office they occupied continue to flaunt their ill-gotten wealth.

Today, a good proportion of workers' salaries cannot adequately cover the food costs, tuition fees, transportation to work, and other basic amenities, yet some privileged individuals are on daily basis cornering the nations collective wealth, thereby endangering society's progressive functioning, thus putting its existence into serious peril (Basu \& Bhattacharya, 1992; Bardhan, 1997; Gire, 1999; Omoluabi, 1995; Akinfala, 2005; Ojedokun \& Eraye, 2012; Balogun, Selemogwe \& Akinfala, 2013). It a common place knowledge in Nigeria in the last two decades that funds that would have been invested in infrastructural and development projects are seriously depleted through kickbacks, over and under invoicing of contract amounts, etc. which accounts for why the grants and aids which are given by richer and developed countries are suspended or sometimes out rightly 
cancelled when it was discovered that these funds are embezzled and end up in corrupt hands (Ayobolu, 2006; Sachs, 2007; Ogunlana, 2011; Owolabi and Babalola).

Two three decades ago, Nigerian used to have values, particularly dignity of labour, zero tolerant to extravagant life style and corrupt tendencies. In fact, before now, a good number of people had climbed up the ladder of needs and were striving for such upper-level needs as esteem and recognition hoping and believing that if they work hard they will surely succeed (Gire, 1999). It is unfortunate to note that, today, hard work is relative and can only be sustained when one is rightly positioned in that vantage position of winner takes all. Gone are those days when public and private sector workers could think of working hard and being competitively placed with colleagues at similar levels in other countries.

Unlike now, people within the regular civil service could aspire to reach the top in their various areas of service in order to have that sense of fulfillment (Gire, 1999). But what do we experience today, it is almost unconceivable to think that these kinds of people would be focused enough to continue to endure in their state of lack to the top, when certain privileged few (both public and private sector office holders) are flaunting ill-gotten wealth (see Owolabi \& Babalola, 2011). It therefore continues to appear to many that "monkey dey work, baboon dey chop" as they say. The advent of ostentatious, extravagant life style of political and numerous privileged private sector office holders has done much harm to the psyche of an average Nigeria. The resultant effects of these unfolding malady was the complete loss if interest in hard work, dignity of work, and "get-reach-quick" syndrome. It does appeared that these privileged individuals are depriving many of most basic needs of life and therefore, people are no longer worried about self-respect or recognition to the same degree, since the lower needs must first be satisfied (Gire, 1999). Therefore, in order to satisfy individual survival instinct as exemplified by Maslow's needs hierarchy theory, people engaged in all manner of fraudulent behaviours, and corrupt practices to obtain supposedly deprived psychological states. In this clime, an average Nigerian wants to live "big" whether it is within his or her income; whether it is at the expense of another person life or fortune it does not matter. Having considered the danger posed by this unfolding phenomenon and the seeming major policy defect in the much orchestrated phenomenon of corruption in Nigeria, by governments and the mass media, this study was initiated. The objective of the study was to fill the knowledge gap in terms of the dearth of objective psychological tools for measuring and predicting corrupt behaviour and other forms of psychological malaise. The development and validation of Extravagant Life-style Assessment Scale (ELAS) is one the bold attempt at remediating an aspect of the policy defect in view of the fact that extravagant life style has implication for the manifestation of corrupt and fraudulent behaviour.

\section{Literature Review}

Different scholars from social sciences, psychology, political sciences and religious studies have attempted a working definition for corruption from their various disciplines. However, all of the working definitions are interwoven. The most relevant definition to this paper is the one given by World Bank, Akindele (1995) and Osoba (1998). The World Bank defines corruption as the abuse of public office for private gain. Akindele (1995) defines it as any form of reciprocal behaviour or transaction where both the power/office holder can respectively initiate the inducement of each other by some rewards to grant (illegal) preferential treatment or favour against the principles and interest of specific organization (or public) within the society. Overall, corruption covers such acts as: - use of one's office for pecuniary advantage, - gratification, - influence peddling, insincerity in advice with the aim of gaining advantage, - less than a full day's work for a full day's pay,- tardiness and slovenliness. Osoba (1998) and Sedadyo \& Haan (2011) sees corruption as all forms of anti-social behaviour conferring improper benefits contrary to legal and moral norms, and which undermine the authoritie to improve the living conditions of the people. Dike (2011) notes that though some of these definitions of corruption have been around for over decades, the recent development in Nigeria where discoveries of stolen public funds run into billions of US Dollars and Nigeria Naira, make these definitions very adequate and appropriate. He further observes that corruption is probably the main means of accumulating quick wealth in Nigeria corruption occurs in many forms, and it has contributed immensely to the poverty and misery of a large segment of the Nigerian population. Corruption has become institutionalized in Nigeria (Olagunju, 2012).

Corruption involves securing wealth or power through illegal means for private gain at public expense; or a Misuse or misapplication of public power for private benefit (Odubunmi \& Agbelade, 2014). Corruption was also known to have coexisted with human society for a long time and remains as one of the problems in many of the world's developing economies with devastating consequences public and private sector functioning, as well as economic growth (Knacks, 1995, Kaufman, Prahan \& Ryteman, 1998; Lambsdorff, 2000; Agbu, 2001, Lambsdorff, 2005). This is phenomenon that seems to have assumed a global dimension, particularly in the developed countries is probably not unconnected with rent-seeking behaviour of people that have administrative or market power (Krurger, 1974; Laffont \& Triole, 1991; Murphy, Schleifer, Vishny, 1993; Odubunmi \& 
Agbelade, 2014; Ogunlana). It is one of the greatest challenges of the contemporary world. It undermines good government, fundamentally distorts public policy, leads to the misallocation of resources, harms the private sector and private sector development and particularly hurts the poor (Transparency International).

Empirical studies have shown that African countries exhibit relatively high level of corruption which institutes a major constraint to efforts aimed at effectively allocating resources to growth enhancing project (Omoluabi, 1995; Akinfala, 2005; Ojedokun \& Eraye, 2012; Odubunmi \& Agbelade, 2014). Rijckeghem and Weder (1997) in their study The extent to which salaries is linked to the amount of corruption was examined by of 28 developing countries found a significant negative influence on the level of corruption of civil service wages relative to manufacturing wages. They argue that low salaries force public servants to supplement their incomes illicitly. La Porta et al. (1997) has also identified Level of trust, religious, tribal and gender differences as factors responsible for corruption. In a sample of 33 countries, the authors show that trust has a significant negative impact on corruption, while controlling for GDP per head.

Lambsdorff (1999) characterized corruption into; bribery, embezzlement, fraud and extortion. Kaufman 1997) opines that there was an old myth that corruption by its "intrinsic nature" is impossible to measure and this has led to lack of serious empirical analysis on corruption. In the past, there was a consensus that real magnitude of corruption cannot be measured. According to Farida and Ahmadi-Esfahani (2007) the obvious difficulties in measuring corruption have not kept a number of entrepreneurs, multilateral development banks, and academics from attempting to do so. Lambsdorff (1999) stresses that it is often difficult to accept the many limitations of the various measures of corruption and that all widely used 'scientific' methods in the field of corruption evaluation hold value in achieving the goal, that is, to estimate the spread and map the structure of corruption. The first was identified by Akerlof (1985) as general perception which is regularly used as a sensitive core indicator to measure corruption through the feeling such as 'lack of justice' in public transactions. Also, the incidence-based approach as identified by Knack (1995), Murphy (1993), Bardhan (1997) and Mandapaka (1995). The current effort is a bold attempt to development a framework for establishing corrupt tendencies as manifested in extravagant life style among Nigerians.

\section{Method}

\subsection{Sample}

Six hundred (600) individuals comprising 378 (63\%) males and 222(37\%) females participated in the study. $47.8 \%$ of the participants are married, $32.1 \%$ are unmarried while $20.1 \%$ constituted those whose marital status were not specified. The participant equally provided very varied background in terms of their religious persuasions. While $40.90 \%$ represented participants with multi-Christian religious affiliations: $38.1 \%$ are of the Islamic religion: 9.9\% represent those whose religions are unclassified (e.g., Gray message, traditional etc) while $11.1 \%$ of the participants did not specify their religious persuasion.

\subsection{Development of ELAS}

The study was carried out among workers in the south-western part of Nigeria at two specific cities: Lagos and Abuja. Workers of Lagos State Ministry of Environment, Health and justice, as well as Workers of federal Ministry of Finance, Health and Justice participated in the instrument standardisation exercise.

This Phase was segmented thus: Step 1: item generation and Step 2: item analysis. The choice of these participants was basically informed by the nature of their similar socio- economic characteristics and group homogeneity. This makes the group similar in all respects to those who participated in the Phase 2 validation exercise.

\subsection{Procedure}

The development of the scale involved two major phases. The first phase has to do with the generation of the scale items that were used to construct the ELAS and the second involved the establishment of the reliability and validity of the intended instrument. The development of the items for the ELAS was not limited to their evolvement from literature. It relied on a combination of three techniques: literature review, content analysis and critical incidents. The literature review generated the first set of items that was included in the ELAS. Secondly, a content analysis of responses to questions on ELAS in interviews with120 people was conducted .The responses were analysed for content pertaining to ELAS. This preliminary investigation was carried out using the interview that took between ten to thirty minutes. Questions in the typical interview sessions were based on the concept of ELAS. Thirdly, Flanagan's 1954) (critical incidents method was applied. Some of the respondents were also asked detailed questions on their extravagance life style experiences. 


\subsection{Construction of Items}

The steps followed in the development of Inventory were (a) the determination of the attribute to be measured, (b) generation of items from the statements that are regularly used to describe contemporary corrupt and fraudulent behaviours, (c) choosing appropriate scaling procedures that are consistent with the summative linear model (Likert, 1932). Likert (1932) method of summate rating is consistent with the summate model for scaling responses. Ajzen \& Fishbean $(1975 ; 1980 ; 2005)$ have provided guidelines on the adoption of the Likert techniques. The researcher generated items for the ELAS-Inventory from the following sources:

(a) 47-items/statements were generated from fraudulent and corrupt tendencies description exercise among prospective job applicants.

(b) Consultations with forensic experts and some selected EFCC and ICPC officers was done to obtain their judgment and criticism as well as face validity of the items. This exercise reduced the original 38 .

(c) These items were later administered to 367 workers in the private and public sectors in the Lagos metropolis of Nigeria. They were requested to rate the items on a 5-pointscale from "highly descriptive", "somehow descriptive", "undecided", "not descriptive" to "not at all descriptive", to indicate agreement that each item measure an important aspect of fraudulent, corrupt and extravagant life. This exercise brought the number of items down to 36 .

\subsection{Trial Testing of ELAS-Inventory}

The 36-items ELAS-Inventory was administered to two 464 workers from both private and public organizations. The sample comprised one hundred- (236) males and 228 females, respectively selected by accidental sampling from gainfully employed part-time MBA students of University of Lagos during the 2007/2008, 2008/2009,2010/2011 sessions, who were employed with private and public organization. In all, two hundred questionnaires were distributed, while only 387 were returned fully completed given a response rate of $83.4 \%$.

\subsection{Exploratory Factor Analysis}

Data obtained from 387 participants were subjected to factor analysis to detect factorial structure or the relationships between variables on the 34-item instrument, and also to examine the interrelationships of the items and to detect items with least latent roots for deletion in line with Ford, MacCallum and Talt (1986) and Schwab (1980). The subject-to-item ratio was approximately 4. Principal component factoring procedure with varimax rotation was used to factor analyze the data. From the result according to the cluster of items, a an eight factor solution emerged and are labelled as: investment - 6 items, Gambling -1 items, Good life -5 items, Religion -2, Social activities -5 items, Family -2 items, Spiritualist -3 items, and Womanising -3 items, respectively. In line with Kaiser's criterion for item inclusion (Child, 1979), items with latent roots less than 1 were removed or deleted.

Further, Meryer-Olkin (KMO) measure of sampling adequacy and Barlett's test of sphericity was computed. The result revealed acceptable KMO, and significant chi-square in line with Brace, Kemp \& Snelgar, (2006). This confirmed that the instrument is indeed factorable and useful. It also show clearly that the respondents perceived eight independent extravagant behaviours.

\section{Results}

The item pool consisting of 84 items written as face validity measures of ELAS was then presented to expert judges (social, developmental, clinical and industrial psychologist) in the department of psychology, university of Lagos for scrutiny. The judges were given the construct definition of ELAS and items were retained in the instrument if considered relevant, essential, meaningful and properly worded by the experts. Justification for this was derived from the assertion that the use of expert technique is an acceptable method for achieving content validity (Nunnally, 1978). The expert ratings were used to calculate content validity and all items that received $80 \%$ support (i.e.4 judges support) were retained. Using a 5- point likert type format, the resultant item pool consisting of 34 items was put in a questionnaire format and administered in a pilot study $(\mathrm{n}=100)$. The instrument items were then subjected to item analysis procedure to ascertain the psychometric properties of the scale and improve on the construct validity of the instrument (Rust \& Golombok, 1995). Items were selected if they have a wide distribution of response alternatives on the item. (Rust \& Golombok, 1995). Using these criteria, 34 items were chosen from the original pool for the final scale. The 34 items devised scale (see appendix 1) has a potential range of .71 .

In order to determine the concurrent, construct and divergent validities of ELAS, the Pearson Product Moment Correlation Coefficient ( $r$ ) was used to intercorrelate ELAS with other standardized measures such as the 
following: Psychopathic Deviate Scale (PD Scale) which is a sub-scale of the Minnesota Multiphasic Personality Inventory (MMPI) by (Hathaway \& Mckinley, 1943), comprising 50 self- reference statements used to measure the degree of psychopathy in adults and delinquency in adolescents. The Organizational Commitment Questionnaire (OCQ) designed by Mowdays, Steers and Porter (1979). It comprises 15 items, which are measured on a reversing 7- point Likert type rating scale from "Strongly Disagree" to "Strongly Agree". The Job Descriptive Index (JDI developed by Smith, Kendall and Hulin (1975), consists of 72 items, some of which assess job satisfaction in terms of pay, work itself, co-workers, supervisor and promotion. The Job Involvement Questionnaire (J1Q) by Kanugo (1982) has 15 items for measuring the degree of involvement of an individual on a particular job on a six- point scale ranging from "Strongly agree" to "Strongly disagree". The Eysenck Personality Questionnaire (EPQ) developed by Eysenck \& Eysenck (1964) used in assessing three personality characteristics, which are extroversion - introversion, (El) neuroticism $(\mathrm{N})$ and psychoticism $(\mathrm{P})$ and Lie $(\mathrm{L})$. The EPQ (Adult) consists of 90 items. The Arrow Dot Test (ADT). Which is a sub test of the IES, I-Id, E-Ego, S-Superego, developed by Dombrose and Slobin (1958). The ADT measure the relative functioning of the three psychoanalytic personality structures of an individual, the ID (I), The Ego (E) and The Superego (S). The Arrow Dot Test requires the solution of 20 graphic problems with 23 responses.

A participant is required to draw the shortest possible line from the point of an arrow to a dot. Between the two are conditional barriers expressed as solid lines and black bars as well as other barriers. The Arrow represents impulsive forces while DOT is a goal to be attained. Heavy bars and single lines are real external barriers to the goal. Dashed or broken lines and gapped bars represent internal pseudo-barriers since they can be crossed within the framework of the instructions. Participants are expected to react in these situations as they would in their everyday behaviours. Crossing the bar or line when alternate routes are available, that is. Ignoring the prohibitions indicates an (Id) response and taking the correct shortest line, and E (ego) score or response. The E score is a measure of the extent to which the participants follow instructions thus mixing conformity with reality. It reflects how far the participants do exactly what they were instructed to do. In contrast S scores and I are the degrees and the manners in which participants do not follow instructions.

Correlation matrix of the measures used shows that out of the 136 correlation coefficients observed, 76 are significant and the remaining 60 are not significant. There are 85 positive and 51 negative correlations. The highest positive correlation of .66 was obtained between JDIc and JD1b. Other high positive coefficients were also obtained between OC loyalty and OC identification, .58; between JDIe and JDId .57.Similarly significant negative correlations were obtained between Arrow Dot Ego and Arrow Dot Id 0.45; Arrow Dot Superego and Arrow Dot ego, -.26; Arrow Dot Superego and Arrow Dot Id, -.25; Job involvement and OC Job, -.25. The lowest negative correlation was obtained between Arrow Dot ego and OC job, -.. 01.

Concurrent Validity coefficients (from the scales that appear to measure similar traits) were observed between Job involvement (JI) and OC Job, - .25; JI and OC identification, -.18; Ji and OC -.11; J1 and JD Id -.13. Arrow Dot Egos and Arrow Dot -. 45; Arrow Dot superego and Arrow Dot ego, -. 26; Arrow Dot Superego and Arrow Dot Id, -.25; Job involvement and OC Job, -.25. Divergent Validity coefficients (from the scales that measure dissimilar traits) were observed between PD and EPQe, .07; JI and Arrow Dot Id, .04; ELAS and PD, .18 JDIa and Arrow Dot ego, .07 . Construct Validity coefficients (from the traits that theoretically predict each other) were observed between EPQ and Arrow Dot id, .08; EPQ $\mathrm{n}$ and Arrow Dot ego, -. 05. The new test ELAS (Extravagant Life-Style Assessment Scale) had reasonable concurrent validity coefficients with EPQp .32, JDIb .22, JDIc, .17, PD .18, Arrow Dot-Id .17. Similarly it had appropriate divergent validity coefficients with JDI-a -. 0, JDI-e -.0, OC-loy -.0 and Arrow Dot Super Ego - .05 .

The second step was to find the factorial validity of Extravagant Life Style Assessment Scale (ELAS). The method of Principal Component Analysis was used to perform the factor analysis of the scores of the 34 items of ELAS. The results show that 8 factors with eigenvalues greater than 1 were extracted. The results are presented in Table 1 below. 
Table 1. Eigenvalues and percentage variance of the factors extracted

\begin{tabular}{llll}
\hline Factors & Eigen-values & \%age of Variance & Cumulative \% \\
\hline 1 & 8.77 & 25.8 & 25.8 \\
2 & 3.28 & 9.60 & 35.4 \\
3 & 1.92 & 5.60 & 41.1 \\
4 & 1.63 & 4.80 & 45.9 \\
5 & 1.37 & 4.00 & 49.9 \\
6 & 1.27 & 3.70 & 53.6 \\
7 & 1.22 & 3.60 & 57.2 \\
8 & 1.03 & 3.00 & 60.2 \\
\hline
\end{tabular}

The results show that the 8 factors ranged in order of magnitude from 1.03 to 8.77 eigenvalues and they accounted for $60.2 \%$ of the total variance for the scale. This tends to suggest the appropriateness of the test (scale) in this study. After Varimax rotation, the loading of each of the items of ELAS on each of the 8 factors was found and the result is presented in Table 2.

Table 2. Summary of factor analysis of ELAS

\begin{tabular}{|c|c|c|c|c|c|c|c|c|c|}
\hline Extracted Factors & Items loadings & 1 & 2 & 3 & 4 & 5 & 6 & 7 & 8 \\
\hline \multicolumn{10}{|l|}{ 1. Investments } \\
\hline V12 & Buying expensive cars & .554 & - & - & - & - & - & - & - \\
\hline V20 & Building houses & .726 & - & - & - & - & - & - & - \\
\hline V22 & Acquiring landed properties & .811 & - & - & - & - & - & - & - \\
\hline V23 & Acquiring shares in companies & .708 & - & - & - & - & - & - & - \\
\hline V24 & Making overseas trips & .748 & - & - & - & - & - & - & - \\
\hline V25 & Saving in foreign banks & .732 & - & - & - & - & - & - & - \\
\hline V26 & Starting new business ventures & .615 & - & - & - & - & - & - & - \\
\hline \multirow[t]{2}{*}{ 2. Gambling } & & - & - & - & - & - & - & - & - \\
\hline & Pool betting /gambling & - & .682 & - & - & - & - & - & - \\
\hline 3. good Life & & - & - & - & - & - & - & - & - \\
\hline V14 & Eating good food & - & - & .660 & - & - & - & - & - \\
\hline V15 & Enjoying life & - & - & .437 & - & - & - & - & - \\
\hline V16 & The needy and less privilege people & - & - & .572 & - & - & - & - & - \\
\hline V32 & Taking care of my health & - & - & 724 & - & - & - & - & - \\
\hline V34 & Saving for the raining day & - & - & 684 & - & - & - & - & - \\
\hline 4. Religion & & - & - & - & - & - & - & - & - \\
\hline V10 & Contributions to church/mosque activities & - & - & - & .657 & - & - & - & - \\
\hline V17 & My aged parents & - & - & - & .585 & - & - & - & - \\
\hline 5. Social activities & & - & - & - & - & - & - & - & - \\
\hline V5 & Paying the dues of my social clubs and societies & - & - & - & - & .608 & - & - & - \\
\hline V11 & Contributions to my town union & - & - & - & - & .545 & - & - & - \\
\hline 27 & Keeping blackmailers qiet & - & - & - & - & .522 & - & - & - \\
\hline V28 & Increasing my social prestige & - & - & - & - & .470 & - & - & - \\
\hline V29 & Sporting activities & - & - & - & - & .405 & - & - & - \\
\hline 6. Family & & - & - & - & - & - & - & - & - \\
\hline V03 & Maintaining many wives & - & - & - & - & - & 677 & - & - \\
\hline
\end{tabular}




\begin{tabular}{|c|c|c|c|c|c|c|c|c|c|}
\hline V04 & Sending many children to school & - & - & - & - & - & .609 & - & - \\
\hline 7. Spiritualist & & - & - & - & - & - & - & - & - \\
\hline V07 & Political activities & - & - & - & - & - & - & 612 & - \\
\hline V08 & Spiritualists and diviners to obtain protection & - & - & - & - & - & - & .807 & - \\
\hline V33 & Warding off spiritual/evil attacks & - & - & - & - & - & - & .437 & - \\
\hline 8. Womanizing & & - & - & - & - & - & - & - & - \\
\hline V01 & Dating women & - & - & - & - & - & - & - & .778 \\
\hline V02 & Throwing lavish parties & - & - & - & - & - & - & - & .418 \\
\hline V13 & Buying expensive clothes/jewelries & - & - & - & - & - & - & - & .466 \\
\hline
\end{tabular}

All the items (from Investment, Gambling, Good life, Religion, Social Activities, Family and Spiritualist) that did not load up to 0.4 on a particular factor in ELAS were dropped. The varimax rotation shows that of the eight ELAS factors with eigenvalues greater or equal to 1 , seven items distinctively loaded on factor 1 ;
1). Buying expensive cars
$(0.554)$
2). Building houses
3). Acquiring landed properties
4). Acquiring shares in companies
5). Making overseas trips
6). Saving in foreign banks
7). Starting new business ventures

However, item 22 (acquiring landed properties) loaded on factor 1 ( 0.811$)$ loaded on both factor 1 and factor 2 , but has the highest loading on factor 1. As such, the item was retained under factor 1.Item 5 (paying the dues of my social clubs and societies) also loaded on factors 4 and 5, but it has the highest loading (0.608) on factor 5 . As such, the item was retained under factor 5.Factor 2 has only one item (pool betting), while factor 3, eating good food (0.660), enjoying life (0.437), the needy and less privileged people $(0.592)$, taking care of my health $(0.724)$ and saving for rainy day (0.684) have five items. In addition, factor 4 has two items, contributions to church/mosque activities $(0.657)$ and my aged parents $(0.585)$. Lastly, on the 34-item scale, five items, Spraying musicians at parties (0.37), Members of my extended family (0.36), Special groups/gangs to protect me (0.44), Renting accommodation for my girl friends/sexual partners $(0.43)$ and the consumption of beer and other alcoholic drinks $(0.18)$ did not load on any factor. It is thus removed from further analysis. The remaining 28 items were retained, since they loaded on the extracted eight factors.

Table 3. Correlation analysis of ELAS variables and fraudulent behaviour

\begin{tabular}{lllll}
\hline S/N & Variables & MEASURES & (r-vlues) & Correlation \\
\hline 1 & Variables 1 & Dating women & .15 & (Low) \\
2 & Variables 2 & Throwing lavish parties & .36 & (Average) \\
3 & Variables 3 & Maintaining many wives & .29 & (Low) \\
4 & Variables 4 & Sending many children to school & .43 & (Average) \\
5 & Variables 5 & Paying the duties of my social clubs and societies & .41 & (Average) \\
6 & Variables 6 & Spraying musicians with money at parties & .37 & (Average) \\
7 & Variables 7 & Funding and sponsoring political parties & .38 & (Average) \\
8 & Variables 8 & Spending on spiritualist and diviners to obtain protection & .29 & (Low) \\
9 & Variables 9 & Engaging in pool bettin/gambling & .44 & (Average) \\
10 & Variables 10 & Contributing to church/mosque activities & .28 & (Low) \\
11 & Variables 11 & Contributions to own town-ship union and developmental project & .38 & (Average) \\
\hline
\end{tabular}




\begin{tabular}{|c|c|c|c|c|}
\hline 12 & Variables 12 & Buying expensive cares & .50 & (High) \\
\hline 13 & Variables 13 & Buying expensive clothes, jewelries and ornaments & .18 & (Low) \\
\hline 14 & Variables 14 & Eating good food & .22 & (Low) \\
\hline 15 & Variables 15 & Enjoying life & .06 & (Very-Low) \\
\hline 16 & Variables 16 & Spending on the needy and less privilege people & .31 & (Low) \\
\hline 17 & Variables 17 & Spending on aged parents & .29 & (Low) \\
\hline 18 & Variables 18 & Spending on extended family & .39 & (Average) \\
\hline 19 & Variables 19 & Engaging groups/gangs with money to protect me & .44 & (Average) \\
\hline 20 & Variables 20 & Spend almost a fortune to erect my living building & .42 & (Average) \\
\hline 21 & Variables 21 & Rented accommodation for my girl-friends/sexual partners & .43 & (Average) \\
\hline 22 & Variables 22 & Spend my savings in acquiring landed properties & .52 & (High) \\
\hline 23 & Variables 23 & Use plenty of money to acquire shares in companies & .48 & (Average) \\
\hline 24 & Variables 24 & Making avoidable/un-necessary overseas trips & .50 & (High) \\
\hline 25 & Variables 25 & Saving in foreign banks & .18 & (Low) \\
\hline 26 & Variables 26 & Engaged my money in starting new business ventures & .45 & (Above-average) \\
\hline 27 & Variables 27 & Use money to keep blackmailers quiet & .50 & (High \\
\hline 28 & Variables 28 & Use money to promote my social prestige & .42 & (Average) \\
\hline 29 & Variables 29 & Funding and sponsoring sporting activities & .06 & (Very-Low) \\
\hline 30 & Variables 30 & Spending on consumption of beer and other alcoholic drinks. & .18 & (Low) \\
\hline 31 & Variables 31 & Using cocaine and other drugs & .34 & (Low) \\
\hline 32 & Variables 32 & Use plenty of my savings to take care of my health & .24 & (Low) \\
\hline 33 & Variables 33 & Use money where necessary to ward off spiritual/evil attacks & .41 & (Average) \\
\hline 34 & Variables 34 & Saving for the raining day & .34 & (Low) \\
\hline
\end{tabular}

The results in Table 3 above show some significant and positive coefficients in all the 34 measures. The highest positive coefficient was found on items $12,22,24$ and 27, followed by items $23,26,9$ and 19. The lowest coefficient was obtained on measures 15 and 29. The results tend to show the extent of influence of ELAS variables on fraudulent behaviour, especially among the Nigerian participants used in the study.

The ELAS reliability is defined as the extent to which it provides the same results. The ELAS adopted the Pearson Product Moment Correlation Statistics to test for the reliability of ELAS; the following reliability coefficients of ELAS were obtained: Split- half .77, Odd and Even .81; Cronbach alpha $=.90$

\section{Discussion}

The study resulted in the identification of Extravagant Life Style Assessment Scale in the Nigerian environment. The study has been able to describe the development and factor structure of the ELAS and presented results that provide strong evidence of reliability and validity of the scale. Items were constructed to cover the range of functions and behavioural aspects ELAS. The scale items were psychologically meaningful as results supported the relationships between scores on the ELAS and that of other construct. The scale will therefore be a very useful instrument for research and counseling in the Nigerian Environment. It will serve both as an instrument to ascertain whether an individual is extravagant or not, and as a vital tool for the management of extravagance in Nigeria.

\section{Conclusion}

Unlike in the past, where there were difficulties in assessing potentialities for extravagancy and ostentatious living among people, the present study has been able to provide Extravagant Life Style Assessment Scale in the Nigerian environment. One of the important findings of this study was that the ELAS scale was extremely versatile as it was able to capture eight dimensions of extravagant or ostentatious spending for which it had been designed. It is presumed that this information and instrument will be of tremendous benefits to staff assessment, 
training and development initiatives in organizations. It has the capacity to growth and development of organisation in terms of raising awareness and building corporate human resources that will effectively minimize corruption and fraudulent behaviours.

\section{References}

Abimbola, A. (2007). Nigeria: Cesspits of corruption. This day newspaper (Lagos) analysis.

Agbu. O. (2003). Corruption and Human Trafficking: the Nigerian case. West Africa Review.

Ajibola, B. (2007). Plea Bargain is Corruption. Sunday Punch.

Akindele, S. T. (1995). Corruption: An Analytical Fuse on the Problems of its Conceptualization. Ife PsycholoGIA, 3(1), 84-85.

Akinfala, F. O. (2005). Fraudulent behaviours among bank employees in Nigeria: a psychological analysis (Unpublished doctoral dissertation). Department of Psychology, University of Lagos, Akoka, Nigeria.

Amadi, S. (2004). Privatizing without reforming: The case of Nigeria. Report of civil society policy dialogue on the national economic empowerment and development strategy (NEEDS) Edited by S. Amadi \& F. Ogwo. A Publication of the Human Rights Law Services (HURILAWS) and Centre for Public Policy \& Research (CPPR).

Balogun, S. K., Selemogwe, M., \& Akinfala, F. (2013). Fraud and extravagant life style among bank employees: Case of convicted bank workers in Nigeria. Psychological Thought, 6(2).

Bamidele, T. B., Joseph, A. I., \& Oresajo, A. L. (2013). Corruption in Nigeria: An impediment to achieving the millennium developmental goals. Journal of Economics and Sustainable Development, 4(1), 110-116.

Bardhan, P. (1997). Corruption and Development: A Review of Issues. Journal of Economic Literature, 35, 1320-1346.

Basu, K., Bhattacharya, S., \& Mishra, A. (1992). Notes on bribery and the control of corruption.

Dike, V. E. (2011). Corruption control: A new paradigm for effective control in Nigeria. Retrieve from http://www.Nigeriaworld.com/feature/article/corruption .html

Dormbrose, L. A., \& Slobin, M. (1958). The I.E.S. Test. Perceptual and Motor Skills, 347-377.

Eysenck, J. H. (1962). Biological Basis Of personality. London: Leonard \& Virginia.

Flanagan, J. C. (1954) The critical incident technique._Psychological Bulletin, 51(1), 327-358.

Gire, J. T. (1999). A psychological analysis of corruption in Nigeria. Journal of Sustainable Development in Africa, 1(2), 1-15.

Hathaway, J., \& McKinley, B. (1943). Personality: Prediction and Prevention: Advances in Behaviour Research and Therapy.

I.C.P.C. (2006). Nigeria and Corruption. Independent Corrupt Practices and Other Related Offences Commission.

Jain, A. K. (1998). Economics of Corruption. Boston, MA: Klewer.

Kaufman, D., Pradhan, S., \& Ryterman, R. (1998). New Frontiers in Anti Corruption Empirical Diagnostics. World Bank Economic Development Institute Working Paper, World Bank.

Knack, K. (1995). Institutions and Economic Performance: Cross Country Tests Using Alternative Institutional Measures. Economics and Politics, 7, 207-227.

Krueger, A. O. (1974). The Political Economy of the Rent-Seeking Society. The American Economic Review, 64, 291-303.

La Porta, R., Lopez-de-Silanes, F., Shleifer, A., \& Vishny, R. W. (1997). Legal determinants of external finance. Journal of Finance, 52, 1131-1150.

Laffont, J. J., \& Triole, J. (1991). The Politics of Government Decision-Making: a theory of regulatory capture. The Quarterly Journal of Economics, 106, 1089-1127.

Lambsdorff, G. (2000). Background Paper to the Corruption Perceptions Index. Transparency International and Göttingen University.

Lambsdorff, G. (2005). Corruption continues to threaten development. Berlin, Internet Center for Corruption Research. 
Mowday, R., Steers, R. M., \& Porter, L. W. (1979). The measurement of Organisational Behaviour. Journal of Vocational Behavior, 14, 224-482.

Murphy, K. M., Schleifer, A., \& Vishny R. W. (1993). Why Rent Seeking So Costly to Growth. American Economic Review, 409-414.

Nunnally, J. C. (1978). Psychometric Theory (2nd ed.). New York: McGraw-Hill.

Ojedokun, U. A., \& Eraye, M. C. (2012). Socioeconomic lifestyles of the yahoo-boys: A study of perceptions of university students in Nigeria. International Journal of Cyber Criminology, 6(2), 21001-1013.

Omoluabi, P. F. (1995). Psychological strategies for detecting and preventing fraud in organizations. In R. Egwuonwu (Ed.), Corporate Financial Risk Exposure Management (pp. 391-421).

Osoba. S. (1998). Corruption in Nigeria: Historical Perspectives. Review of African Political Economy (ROAPE), 23(69), 371-386.

Owolabi, A. B., \& Babalola, S. S. (2011). Effect of perceived inequality and perceived job insecurity on fraudulent intent of bank employees in Nigera. Europe's Journal of Psychology, 7(1), 199-111.

Rijckeghem \& Weder. (1997). Corruption and the rate of temptation: Do low wages in the civil service cause corruption? IMF Working Paper.

Rust, \& Golombok, S. (1995). Modern Psychometrics: The science of Psychological assessment. New York: Routledge.

Seldadyo, H., \& Haan, J. D. (2006). The determinants of corruption: A literature survey and new evidence. A paper presented at the ESCS Conference, Turku, Finland, 22-23 April.

Smith, P. C., Kendall, L. M., \& Hullin, C. L. (1975). The measurements of satisfaction in work and retirement Chicago: Round Menally.

\section{Copyrights}

Copyright for this article is retained by the author(s), with first publication rights granted to the journal.

This is an open-access article distributed under the terms and conditions of the Creative Commons Attribution license (http://creativecommons.org/licenses/by/3.0/). 